\title{
EKSPLORASI MODA ASAL PENGGUNA TRANSPORTASI ONLINE DI KOTA BANDUNG
}

\author{
Muhamad Rizki \\ Program Studi Teknik Sipil \\ Universitas Katolik Parahyangan \\ Jln. Ciumbuleuit No. 94 \\ Bandung 40141 \\ muhamadrizki1404@gmail.com
}

\author{
Tri Basuki Joewono \\ Program Studi Teknik Sipil \\ Universitas Katolik Parahyangan \\ Jln. Ciumbuleuit No. 94 \\ Bandung 40141 \\ vftribas@unpar.ac.id
}

\author{
Jeanly Syahputri \\ Program Studi Teknik Sipil \\ Universitas Katolik Parahyangan \\ Jln. Ciumbuleuit No. 94 \\ Bandung 40141 \\ jeanlysyahputri@gmail.com
}

\begin{abstract}
The rise of ride-sourcing service for cities mobility has change how people do travel and consequently disrupt transport ecosystem. This paper explore the travel behavior of ride-sourcing users based on travellers' previous modes using discriminant analysis. For the purpose, the study collected data from a survey in the Bandung City in 2018. Analysis confirms the substitution effect of ride-sourcing from both private and public transport. Substitution effect occur from public transport than private car that tend to associated with younger traveller which have limitation access for private transport. The analysis found that ride-sourcing might be used for specific purposes only rather than for daily commuting, especially for users who previously use private car.
\end{abstract}

Keywords: ridesourcing, previous mode, public transport, travel behavior

\begin{abstract}
Abstrak
Munculnya penggunaan angkutan online dalam mobilitas perkotaan telah mengubah cara orang melakukan perjalanan dan akibatnya mengganggu ekosistem transportasi. Makalah ini bertujuan untuk mengeksplorasi perilaku perjalanan pengguna angkutan online berdasarkan moda berkendara sebelumnya menggunakan analisis diskriminan. Untuk tujuan tersebut, pada penelitian ini dikumpulkan data dari survei primer yang dilakukan di Kota Bandung pada tahun 2018. Analisis mengonfirmasi efek substitusi angkutan online transportasi pribadi dan transportasi publik. Efek substitusi terjadi dari angkutan umum daripada mobil pribadi yang cenderung merupakan pelaku perjalanan muda yang memiliki akses terbatas untuk angkutan pribadi. Analisis yang dilakukan menemukan bahwa angkutan online mungkin hanya digunakan untuk tujuan tertentu daripada untuk perjalanan sehari-hari, terutama untuk pengguna yang sebelumnya menggunakan mobil pribadi.
\end{abstract}

Kata-kata kunci: angkutan online, moda sebelumnya, transportasi publik, perilaku perjalanan

\section{PENDAHULUAN}

Sebagai bagian inovasi dalam teknologi informasi dan komunikasi, angkutan online telah berkembang dalam memfasilitasi masyarakat dalam melakukan perjalanan. Pelaku perjalanan dapat mengakses pelayanan angkutan online melalui telepon genggam yang terhubung dengan informasi perjalanan, seperti tarif, waktu tempuh, dan waktu tunggu. Pelayanan angkutan online ini telah terbukti memberikan kepastian waktu tunggu, penghematan biaya transportasi, serta penurunan waktu tempuh daripada angkutan lain (Irawan et al., 2019). Perkembangan angkutan online ini telah terjadi di berbagai negara di dunia, 
seperti di Amerika, di Eropa, dan di Asia. Di Indonesia, angkutan online memulai pelayanannya pada tahun 2014 dengan aplikasi Go-Jek. Aplikasi Go-Jek pada tahun 2018 telah melayani perjalanan lebih dari 4 milyar kilometer pada 50 kota di Indonesia (Silalahi et al., 2017).

Perkembangan angkutan online di sisi lain telah berdampak pada angkutan eksisting, baik angkutan pribadi maupun angkutan umum. Lavieri et al. (2018) mengatakan bahwa angkutan online telah mengubah ekosistem transportasi dengan dampaknya terhadap angkutan yang ada. Secara spesifik, dampak adanya angkutan online pada angkutan lainnya dapat diklasifikasikan menjadi 2 macam, yaitu dampak substitusi dan dampak komplementer (Rayle et al., 2016). Dampak substitusi adalah dampak angkutan online yang menggantikan fungsi angkutan lainnya dalam melakukan perjalanan, sedangkan dampak komplementer merupakan dampak angkutan online sebagai angkutan pelengkap angkutan lainnya.

Perkembangan penggunaan angkutan online dipastikan masih akan terus meningkat pada dekade mendatang. Peneliti dari berbagai disiplin ilmu tertarik dalam menginvestigasi dampak angkutan online kepada perilaku perjalanan, perkotaan, dan lingkungan. Studi oleh Clewlow dan Mishra (2017) menunjukkan bahwa angkutan online dapat meningkatkan pengguna kereta komuter namun berdampak penurunan pengguna kereta ringan dan bus di kota-kota di Amerika Serikat. Di Toronto, Kanada, angkutan online menurunkan pengguna taksi dan mobil pribadi serta meningkatkan pengguna angkutan umum (Young dan Farber, 2019). Dias et al. (2017) mengindikasikan bahwa angkutan online dapat menurunkan perjalanan nonmotor, seperti pejalan kaki dan pengguna sepeda.

Di Indonesia, dampak angkutan online telah sangat terasa pada angkutan lainnya. Nangoy dan Silviana (2016) melakukan wawancara pada operator taksi di Indonesia yang menyatakan bahwa angkutan online telah melakukan penghancuran terhadap usaha taksi. Pada perkotaan, seperti Bandung, para sopir angkutan kota mengatakan bahwa terjadi penurunan signifikan dari pengguna setelah adanya angkutan online (Mutiah, 2017). Studi angkutan online di Indonesia (Irawan et al., 2019; Medeiros et al., 2018) menemukan bahwa dampak angkutan online kepada angkutan umum sangat bervariasi. Studi Medeiros et al. (2018) menemukan bahwa dampak angkutan online kepada angkutan umum dapat menjadi substitusi maupun komplementer. Sedangkan studi Irawan et al. (2019) menemukan bahwa angkutan online berdampak positif kepada pengguna angkutan umum bus dan kereta komuter di Jakarta.

Dengan hasil studi sebelumnya dan pendapat operator angkutan umum, dampak angkutan online terhadap angkutan eksisting masih sangat bervariasi. Studi ini menginvestigasi perilaku pengguna angkutan online berdasarkan angkutan yang digunakan sebelum adanya pelayanan angkutan online yang pada penelitian ini didefinisikan dengan angkutan sebelumnya. Investigasi perilaku pengguna berdasarkan angkutan sebelumnya akan menambah pemahaman akan dampak angkutan online kepada angkutan eksisting serta dapat 
menjadi bagian dalam rangka masukan terhadap kebijakan peningkatan fungsi angkutan online sebagai komplementer dari angkutan umum.

Penelitian ini menggunakan kuesioner yang didistribusikan kepada pengguna angkutan online di Kota Bandung. Kuesioner ini terdiri atas pertanyaan yang mencakup aspek sosio-demografi, seperti pendapatan, status keluarga, dan status rumah, serta aspek perilaku penggunaan angkutan online, termasuk karakteristik perjalanan, seperti waktu tempuh, waktu tunggu, dan tarif. Kuesioner dibagikan di 6 wilayah administratif Kota Bandung, yaitu Tegallega, Gede Bage, Ujung Berung, Karees, Cibeunying, dan Bojonagara. Pendistribusian dilakukan pada tanggal 24 April 2018 hingga tanggal 14 Mei 2018, dengan bantuan 20 surveyor. Ukuran sampel sebanyak 400 ditentukan berdasarkan persamaan Yamane (Israel, 2012) dengan acuan populasi Kota Bandung sebanyak 2.481.469 jiwa (BPS Kota Bandung, 2017) dan tingkat signifikansi 5\%. Ukuran sampel ditingkatkan menjadi 520 untuk mengatasi peluang terjadinya kesalahan selama survei. Setelah distribusi kuesioner selesai, data dievaluasi berdasarkan kelengkapannya, dan diperoleh hasil bahwa 497 set dapat digunakan untuk analisis lebih lanjut.

Dalam memperoleh keterangan jenis angkutan yang digunakan saat belum terdapat pelayanan angkutan online, dilakukan wawancara kepada responden dengan memberikan opsi kendaraan yang digunakan pada 3 kategori, yaitu sepeda motor, mobil pribadi, dan angkutan umum. Secara spesifik angkutan pribadi, yaitu sepeda motor dan mobil, merupakan representasi bentuk substitusi angkutan online untuk pergerakan dengan kendaraan pribadi. Sedangkan angkutan umum merupakan bentuk substitusi pengguna kendaraan umum ke angkutan online. Tabel 1 menunjukkan bahwa dari seluruh responden, hampir mayoritas merupakan pengguna kendaraan pribadi. Dengan pengguna kendaraan sepeda motor sebelumnya mendominasi $(58,8 \%)$ dan pengguna kendaraan mobil $(23,1 \%)$ setelahnya.

Hanya $18,1 \%$ responden yang merupakan representasi pengguna angkutan umum sebelum adanya angkutan online. Selanjutnya, berdasarkan pendapatan, mayoritas responden, yang sebelumnya menggunakan sepeda motor dan angkutan umum, memiliki pendapatan pada rentang (3-6) juta rupiah per bulan. Sedangkan responden pengguna mobil, pada periode angkutan online belum melayani, mayoritas memiliki pendapatan lebih besar daripada 12 juta rupiah.

Berdasarkan karakteristik perjalanan, terdapat deskripsi responden berdasarkan waktu tunggu, waktu tempuh, dan tarif. Mayoritas waktu tunggu responden berkisar antara 5 menit hingga 10 menit. Mayoritas waktu tempuh responden terdapat pada rentang (30-60) menit. Rata-rata tarif yang dikeluarkan oleh responden, yang sebelumnya menggunakan sepeda motor dan angkutan umum, berkisar pada rentang Rp10.000,00 hingga Rp20.000,00. Sedangkan mayoritas responden pengguna mobil sebelum adanya angkutan online memiliki tarif rata-rata pada rentang Rp20.000,00 hingga Rp30.000,00. 


\section{ANALISIS}

Karakteristik personal dan perjalanan responden dirangkum pada Tabel 1. Analisis diskriminan dilakukan dengan variabel klasifikasi adalah moda sebelumnya dan variabel penjelas adalah karakteristik personal dan karakteristik perjalanan menggunakan angkutan online. Sebelumnya dilakukan uji ANOVA untuk melihat variansi antargrup moda sebelumnya, seperti yang disajikan pada Tabel 2. Analisis variansi dilakukan untuk variabel karakteristik perjalanan, yaitu waktu tunggu, waktu tempuh, dan tarif. Hasil analisis variansi menunjukkan bahwa terdapat variansi pada setiap variabel. Variabel yang signifikan berbeda (signifikan pada 5\%) adalah waktu tempuh dan tarif. Pada sisi waktu tempuh responden yang menggunakan sepeda motor dan yang menggunakan mobil berbeda dengan pengguna angkutan umum. Adapun untuk tarif, responden yang sebelumnya menggunakan sepeda motor dan yang menggunakan angkutan umum berbeda dengan pengguna mobil. Hasil ini menunjukkan bahwa terdapat dugaan perbedaan karakteristik perjalanan berdasarkan moda sebelumnya.

Selanjutnya analisis diskriminan ditampilkan pada Tabel 3. Nilai statistik yang digunakan untuk menunjukkan kualitas analisis diskriminan ini dapat dilihat dari nilai korelasi canonical di setiap fungsi yang menjelaskan bahwa model dapat menjelaskan 25\% variasi. Selain itu, dapat dilihat bahwa nilai kesesuaian klasifikasi pada model menunjukkan nilai lebih besar daripada 55\%. Syarat validasi model ditunjukkan pada nilai signifikansi uji Box-M. Hipotesis null, bahwa grup moda sebelumnya tidak saling berhubungan antargrup, dapat ditolak karena nilai signifikansi yang lebih kecil dari syarat 5\%.

Interpretasi model diskriminan berhubungan dengan fungsi pusat grup (Function of Group Centroid, FGC) yang memisahkan 2 pilihan. Dengan mengevaluasi pilihan dengan nilai paling positif dan negatif, dengan loading yang lebih dari 0,3, dihasilkan 2 fungsi dari 3 grup moda sebelumnya. Fungsi pertama memisahkan responden yang sebelumnya menggunakan mobil $(0,554)$ dan responden yang sebelumnya menggunakan angkutan umum (-1,225). Berdasarkan matrik struktur, variabel bebas yang berasosisasi dengan fungsi 1 adalah jenis kelamin, pendapatan, jenis tempat tinggal, frekuensi penggunaan angkutan online, dan usia. Model menunjukkan bahwa pengguna angkutan online pria atau yang memiliki pendapatan lebih besar dari 9 juta rupiah per bulan cenderung berasosiasi dengan pengguna mobil daripada dengan angkutan umum sebelumnya. Pengguna angkutan online yang berusia kurang dari 18 tahun cenderung menggunakan angkutan umum daripada menggunakan mobil sebelumnya. Dalam aspek penggunaan angkutan online, penggunaan dengan frekuensi rendah cenderung berasosiasi dengan pelaku perjalanan yang sebelumnya menggunakan mobil daripada menggunakan angkutan umum. 
Tabel 1 Karakteristik Personal dan Perjalanan Responden

\begin{tabular}{|c|c|c|c|c|}
\hline \multirow{3}{*}{ 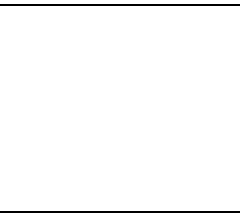 } & \multirow{3}{*}{ Variabel } & \multicolumn{3}{|c|}{ Moda Sebelumnya } \\
\hline & & \multirow{2}{*}{$\begin{array}{c}\mathrm{SM} \\
\mathrm{N}=292 \\
58,8 \%\end{array}$} & \multirow{2}{*}{$\begin{array}{c}\mathrm{MB} \\
\mathrm{N}=115 \\
23,1 \%\end{array}$} & \multirow{2}{*}{$\begin{array}{c}\mathrm{AU} \\
\mathrm{N}=90 \\
18,1 \%\end{array}$} \\
\hline & & & & \\
\hline \multirow{5}{*}{ Usia } & $<18$ tahun & 1,4 & 0,0 & 11,1 \\
\hline & $18-25$ tahun & 53,4 & 40,9 & 60,0 \\
\hline & 26-40 tahun & 37,0 & 46,1 & 24,4 \\
\hline & $41-60$ tahun & 7,2 & 11,3 & 3,3 \\
\hline & $>60$ tahun & 1,0 & 1,7 & 1,1 \\
\hline \multirow{4}{*}{ Pendidikan } & Sekolah Menengah Pertama (SMP) & 2,7 & 0,9 & 17,8 \\
\hline & Sekolah Menengah Atas (SMA) & 24,0 & 13,9 & 23,3 \\
\hline & D-1 hingga $S 1$ & 71,9 & 79,1 & 57,8 \\
\hline & $\mathrm{S} 2 / \mathrm{S} 3$ & 1,4 & 6,1 & 1,1 \\
\hline \multirow{8}{*}{ Pekerjaan } & Pelajar/Mahasiswa & 38,0 & 19,1 & 51,1 \\
\hline & Wiraswasta & 18,8 & 16,5 & 11,1 \\
\hline & Tidak Bekerja & 6,5 & 2,6 & 1,1 \\
\hline & Pegawai Negeri/TNI/POLRI & 2,7 & 10,4 & 3,3 \\
\hline & Pegawai Swasta/BUMN/BUMD & 27,1 & 40,0 & 18,9 \\
\hline & Guru/Dosen & 1,0 & 1,7 & 6,7 \\
\hline & Ibu Rumah Tangga & 3,8 & 5,2 & 3,3 \\
\hline & Lainnya & 2,1 & 4,3 & 4,4 \\
\hline \multirow{6}{*}{ Pendapatan } & $<\mathrm{Rp} 1.000 .000,00$ & 2,7 & 0,9 & 3,3 \\
\hline & Rp1.000.000,00-Rp3.000.000,00 & 19,5 & 4,3 & 25,6 \\
\hline & Rp3.000.001,00-Rp6.000.000,00 & 32,9 & 24,3 & 32,2 \\
\hline & Rp6.000.001,00-Rp9.000.000,00 & 16,8 & 20,9 & 23,3 \\
\hline & Rp9.000.001,00-Rp12.000.000,00 & 17,5 & 18,3 & 10,0 \\
\hline & $>\mathrm{Rp} 12.000 .000,00$ & 10,6 & 31,3 & 5,6 \\
\hline \multirow{5}{*}{$\begin{array}{c}\text { Rata-Rata } \\
\text { Waktu Tunggu }\end{array}$} & $<5$ Menit & 28,0 & 17,5 & 34,4 \\
\hline & 5-10 Menit & 44,2 & 53,0 & 46,7 \\
\hline & 11-15 Menit & 19,2 & 24,3 & 15,6 \\
\hline & 16-30 Menit & 6,2 & 5,2 & 2,2 \\
\hline & $>30$ Menit & 2,4 & 0,0 & 1,1 \\
\hline \multirow{5}{*}{$\begin{array}{c}\text { Rata-Rata } \\
\text { Waktu Tempuh }\end{array}$} & $<15$ Menit & 16,8 & 9,6 & 21,1 \\
\hline & 15-30 Menit & 49,7 & 47,8 & 51,1 \\
\hline & 30-60 Menit & 32,2 & 40,0 & 26,7 \\
\hline & 60-90 Menit & 1,4 & 2,6 & 1,1 \\
\hline & $>90$ Menit & 0,0 & 0,0 & 0,0 \\
\hline \multirow{6}{*}{$\begin{array}{l}\text { Rata-Rata } \\
\text { Tarif }\end{array}$} & $<\mathrm{Rp} 10.000,00$ & 6,8 & 2,6 & 12,2 \\
\hline & Rp10.000,00-Rp20.000,00 & 49,7 & 33,0 & 53,3 \\
\hline & Rp20.001,00-Rp30.000,00 & 29,5 & 41,7 & 30,0 \\
\hline & Rp30.001,00-Rp40.000,00 & 9,6 & 14,8 & 2,2 \\
\hline & Rp40.001,00-Rp50.000,00 & 4,1 & 3,5 & 0,0 \\
\hline & $>\mathrm{Rp} 50.000,00$ & 0,3 & 4,3 & 2,2 \\
\hline
\end{tabular}

SM: Sepeda Motor; MB: Mobil Pribadi; AU: Angkutan Umum 
Tabel 2 Hasil ANOVA Karakteristik Perjalanan Berdasarkan Moda Sebelumnya

\begin{tabular}{lcccccc}
\hline \multirow{2}{*}{ Variabel } & Levene & ANOVA & \multicolumn{3}{c}{ Posthoc Test } & \\
\cline { 2 - 6 } & Statistics & F & & \multicolumn{2}{c}{ Moda Sebelumnya } \\
\cline { 2 - 6 } & & & SM & MB & AU \\
\hline Rata-rata waktu tunggu & 2,215 & $2,784^{*}$ & & & \\
Rata-rata waktu tempuh & 0,641 & $4,202 * *$ & & & \\
Rata-rata tarif & 1,193 & $12,882 * *$ & & & & \\
\hline
\end{tabular}

* signifikan pada 10\%; ** signifikan pada 5\%; SM: Sepeda Motor; MB: Mobil Pribadi; AU: Angkutan Umum

Fungsi kedua memisahkan grup pengguna angkutan online yang sebelumnya menggunakan mobil pribadi dengan yang pengguna sepeda motor. Variabel yang signifikan pada fungsi kedua adalah jenis kelamin, pendidikan, dan karakteristik perjalanan. Hasil model menunjukkan bahwa pengguna angkutan online pria cenderung sebelumnya menggunakan sepeda motor daripada menggunakan mobil. Seragam dengan temuan sebelumnya, pengguna angkutan online dengan pendapatan tinggi atau berpendidikan tinggi cenderung menggunakan mobil daripada menggunakan sepeda motor sebelumnya. Adapun pengguna angkutan online sepeda motor cenderung menggunakan sepeda motor daripada menggunakan mobil sebelumnya. Sedangkan pengguna angkutan online rutin cenderung sebelumnya menggunakan mobil daripada menggunakan sepeda motor.

Tabel 3 Analisis Diskriminan Moda Sebelumnya

\begin{tabular}{|c|c|c|c|c|c|c|c|}
\hline \multicolumn{2}{|l|}{ Variabel } & SM & MB & $\mathrm{AU}$ & $\mathrm{F}$ & F1 & $\mathrm{F} 2$ \\
\hline \multicolumn{8}{|l|}{ Karakteristik Personal } \\
\hline \multicolumn{2}{|l|}{ Pria $[D]$} & 0,708 & 0,569 & 0,304 & $23,013 * *$ & 0,457 & $-0,537$ \\
\hline \multicolumn{2}{|l|}{ Pascasarjana [D] } & 0,015 & 0,067 & 0,013 & $4,365^{* *}$ & 0,127 & 0,362 \\
\hline \multicolumn{2}{|l|}{ Pendapatan di atas 9 juta rupiah [D] } & 0,281 & 0,481 & 0,139 & $13,844 * *$ & 0,359 & 0,403 \\
\hline \multicolumn{2}{|l|}{ Tinggal di kontrakan [D] } & 0,187 & 0,115 & 0,342 & $7,685^{* *}$ & $-0,312$ & $-0,084$ \\
\hline \multicolumn{2}{|l|}{ Usia kurang dari 18 tahun [D] } & 0,015 & 0,000 & 0,127 & $15,698 * *$ & $-0,447$ & 0,105 \\
\hline \multicolumn{2}{|l|}{ Usia antara $18-25$ tahun [D] } & 0,532 & 0,414 & 0,557 & $2,553 *$ & $-0,117$ & $-0,251$ \\
\hline \multicolumn{2}{|l|}{ Usia antara $26-40$ tahun [D] } & 0,375 & 0,490 & 0,266 & $4,951 * *$ & 0,227 & 0,200 \\
\hline \multicolumn{2}{|l|}{ Luas tempat tinggal lebih dari $150 \mathrm{~m}^{2}[\mathrm{D}]$} & 0,124 & 0,192 & 0,089 & $2,368 *$ & 0,137 & 0,195 \\
\hline \multicolumn{8}{|c|}{ Karakteristik Perjalanan Menggunakan Angkutan Online } \\
\hline \multicolumn{2}{|c|}{ Pengguna angkutan online sepeda motor [D] } & 0,850 & 0,673 & 0,924 & $11,961 * *$ & $-0,294$ & $-0,47$ \\
\hline \multicolumn{2}{|l|}{ Kurang dari 5 menit waktu tunggu [D] } & 0,273 & 0,164 & 0,329 & $3,674 * *$ & $-0,171$ & $-0,244$ \\
\hline \multicolumn{2}{|l|}{ Rata-rata tarif kurang dari Rp10.000,00 [D] } & 0,067 & 0,029 & 0,089 & 1,526 & $-0,112$ & $-0,152$ \\
\hline \multicolumn{2}{|c|}{ Pengalaman angkutan online $>$ dari 1 tahun [D] } & 0,363 & 0,365 & 0,519 & $3,317 * *$ & $-0,199$ & 0,104 \\
\hline \multicolumn{2}{|c|}{ Frekuensi angkutan online $<$ dari 6 kali per bulan [D] } & 0,749 & 0,769 & 0,443 & $16,121 * *$ & 0,447 & $-0,162$ \\
\hline \multirow{3}{*}{$\begin{array}{l}\text { Box's M [F; df1; df2; p-value] } \\
\text { Eigen Values [Canonical Correlation] } \\
\text { Wilks' Lambda F1 through F2; F2[p-value] }\end{array}$} & \multicolumn{4}{|c|}{$340,908[3,028 ; 105 ; 68251,604 ; 0,000]$} & $\begin{array}{l}\text { Angkutan } \\
\text { Sebelumnya }\end{array}$ & $\mathrm{F} 1$ & $\mathrm{~F} 2$ \\
\hline & \multirow{2}{*}{\multicolumn{3}{|c|}{$\begin{array}{l}0,346 ; 0,107[0,507 ; 0,311] \\
0,671 ; 0,904[0,000 ; 0,000]\end{array}$}} & \multirow{2}{*}{$\mathrm{FGC}$} & SM & 0,154 & $-0,256$ \\
\hline & & & 0,$671 ; 0,904[0,000 ; 0,000]$ & & MB & 0,535 & 0,514 \\
\hline Percent Correct & \multicolumn{4}{|l|}{$58,70 \%$} & $\mathrm{AU}$ & $-1,225$ & 0,187 \\
\hline
\end{tabular}

[D] = variabel dummy 1 jika ya, 0 lainnya; * signifikan pada 10\%; ** signifikan pada 5\%; SM: Sepeda Motor; MB: Mobil Pribadi; AU: Angkutan Umum; FGC: Function at Group Centroid 


\section{DISKUSI}

Temuan pada studi ini adalah pemahaman baru dalam kondisi layanan angkutan online saat ini. Pertama, dari karakteristik responden, pengguna angkutan online tidak hanya pelaku perjalanan yang menggunakan angkutan pribadi, seperti sepeda motor atau mobil, tetapi juga pelaku perjalanan yang menggunakan transportasi umum. Hal ini mengonfirmasi bahwa efek substitusi terjadi dan menegaskan studi yang dilakukan oleh Young dan Farber (2019), bahwa layanan angkutan online dapat memiliki pengaruh negatif dengan membawa pelaku perjalanan berpindah dari angkutan yang lebih berkelanjutan, seperti angkutan umum dan non-motorized transport.

Model klasifikasi mengonfirmasi peran karakteristik pribadi terhadap efek substitusi. Pengguna angkutan online yang lebih muda, dengan umur kurang dari 18 tahun, cenderung sebelumnya menggunakan angkutan umum daripada menggunakan mobil pribadi. Temuan ini berhubungan dengan akses terhadap moda berkendara yang terbatas pada pelaku perjalanan muda, seperti yang dinyatakan pada studi Rizki et al. (2019). Pelaku perjalanan muda cenderung memiliki akses terbatas ke transportasi pribadi, yaitu sepeda motor atau mobil, karena faktor administrasi mengemudi dan sosial-ekonomi. Hal tersebut menyebabkan kelompok ini tidak memiliki pilihan selain menggunakan transportasi umum. Dengan pengembangan angkutan online, pelaku perjalanan ini mendapatkan alternatif baru untuk melakukan perjalanan. Temuan ini menunjukkan bahwa substitusi angkutan umum cenderung terjadi untuk pelaku perjalanan muda. Pengguna angkutan online dengan penghasilan tinggi memiliki kecenderungan berasosiasi dengan penggunaan mobil pribadi daripada penggunaan angkutan umum atau sepeda motor sebelum adanya angkutan online. Temuan ini mengonfirmasi adanya substitusi mobil pribadi yang cenderung berhubungan dengan individu dengan penghasilan tinggi. Pria yang menggunakan angkutan online sebelumnya cenderung menggunakan sepeda motor daripada menggunakan mobil.

Selanjutnya ditemukan bahwa penggunaan angkutan online dengan frekuensi lebih rendah cenderung berasosiasi dengan pengguna mobil pribadi daripada pengguna sepeda motor pada moda sebelumnya. Alasan yang mungkin terjadi adalah pengguna mobil pribadi cenderung menggunakan angkutan online untuk perjalanan sesekali, seperti rekreasi, daripada perjalanan komuter. Ketika individu terlibat dalam berbagai kegiatan dalam sehari, individu tersebut memaksimalkan batasan waktu dan ruang mereka dengan mengoptimalkan perjalanan mereka termasuk dengan memilih moda perjalanan. Temuan ini berhubungan dengan hasil studi yang dilakukan oleh Clewlow dan Mishra (2017), yang menyatakan bahwa penggunaan angkutan online berhubungan dengan jenis atau tujuan perjalanan. Young and Farber (2019) juga menegaskan bahwa ketika mempertimbangkan jumlah perjalanan selama sehari atau dalam seminggu, gambaran yang beragam akan muncul dalam memahami peran angkutan online. 


\section{KESIMPULAN}

Dalam rangka memahami perjalanan pengguna angkutan online, studi ini mengeksplorasi efek substitusi pemanfaatan angkutan online, baik angkutan pribadi maupun angkutan umum. Penelitian ini mendukung temuan penelitian sebelumnya, bahwa efek substitusi bekerja secara berbeda berdasarkan karakteristik pribadi dan moda angkutan sebelumnya.

Pengguna angkutan yang memiliki frekuensi angkutan online yang lebih rendah kemungkinan besar sebelumnya merupakan pengguna mobil pribadi. Hal ini menunjukkan bahwa para pelaku perjalanan dapat menggabungkan moda angkutan online dengan moda lain dalam perjalanan harian mereka atau menggunakan dalam basis mingguan untuk acara tertentu, serta memaksimalkan batasan waktu dan ruang mereka.

Dengan kualitas infrastruktur angkutan umum yang ada dan keterbatasan aksesnya ke lokasi perumahan di Kota Bandung, angkutan online memainkan peran penting untuk mobilitas sehari-hari. Peningkatan dan pengembangan sistem transportasi umum dengan kualitas layanan tinggi harus menjadi agenda utama pembangunan, baik pada tataran Pemerintah Daerah maupun pada tataran nasional untuk, setidaknya, mengurangi penggunaan angkutan online untuk menjadi angkutan utama dan menjadikannya sebagai angkutan pengumpan angkutan umum massal.

Penelitian ini juga memiliki beberapa keterbatasan yang dapat menjadi dasar untuk penelitian lebih lanjut. Perjalanan agregat dalam penelitian ini tidak dapat menangkap dengan sempurna tentang pelaku perjalanan merangkai perjalanan harian mereka dan peran angkutan online dalam perjalanan harian individu. Studi lebih lanjut akan memperluas pengetahuan tentang efek substitusi angkutan online dan menyelidiki efek komplementer potensial untuk meningkatkan penggunaan transportasi umum. Selain itu, studi dari sisi pengemudi angkutan online juga sangat penting untuk mengetahui bagaimana angkutan online memengaruhi kehidupan dan kepuasan pengemudi terhadap pekerjaan sebagai angkutan online. Pemahaman ini dapat menjadi dasar, tidak hanya untuk pemerintah sebagai regulator yang mengatur angkutan online, namun untuk kebijakan kompetisi antarangkutan.

\section{UCAPAN TERIMA KASIH}

Studi ini didanai oleh Direktorat Penelitian dan Pengabdian Masyarakat, Direktorat Jenderal Penguatan Riset dan Pengembangan, Kementerian Riset, Teknologi, dan Pendidikan Tinggi, Republik Indonesia tahun 2018. Penulis mengucapkan terima kasih kepada semua pihak yang telah berpartisipasi dalam pengumpulan data. 


\section{DAFTAR PUSTAKA}

Badan Pusat Statistik Kota Bandung. 2017. Kota Bandung dalam Angka 2017. Bandung.

Clewlow, R.R. dan Mishra, G.S. 2017. Disruptive Transportation: The Adoption, Utilization, and Impacts of Ride-Hailing in the United States. University of California, Davis, Institute of Transportation Studies, Davis, CA, Research Report UCD-ITS-RR-17-07.

Dias, F.F., Lavieri, P.S., Garikapati, V.M., Astroza, S., Pendyala, R.M., dan Bhat, C.R. 2017. A Behavioral Choice Model of the Use of Car-Sharing and Ride-Sourcing Services. Transportation, 44 (6): 1307-1323.

Irawan, M.Z., Belgiawan, P.F., Tarigan, A.K.M., dan Wijanarko, F. 2019. To Compete or Not Compete: Exploring the Relationships Between Motorcycle-Based Ride-Sourcing, Motorcycle Taxis, and Public Transport in the Jakarta Metropolitan Area. Transportation, 1-23.

Israel, G.D. 2012. Determining Sample Size. PEOD6. Agricultural Education and Communication Department, Florida Cooperative Extension Service, Institute of Food dan Agricultural Sciences, University of Florida, Gainesville, FL.

Lavieri, P.S., Dias, F.F., Juri, N.R., Kuhr, J., dan Bhat, C.R. 2018. A Model of Ridesourcing Demand Generation and Distribution. Transportation Research Record, 2672 (46): 31-40.

Medeiros, R.M., Duarte, F., Achmad, F., dan Jalali, A. 2018. Merging ICT and Informal Transport in Jakarta's Ojek System. Transportation Planning and Technology, 41 (3): 336-352.

Mutiah, D. 2017. Makin Ditinggalkan, Perlukah Angkot di Bandung Dipertahankan? (Online), (https://www.liputan6.com/regional/read/2909825/makin-ditinggalkan-perlukah-angkot -di-bandung-dipertahankan, diakses 16 Mei 2019).

Nangoy, F. dan Silviana, C. 2016. Indonesian Taxi Drivers to Rally for Ban on Online Taxi Apps. (Online), (https://www.reuters.com/article/indonesia-taxis-idUSL3N16T28C, diakses 19 Juni 2019).

Rayle, L., Dai, D., Chan, N., Cervero, R., dan Shaheen, S. 2016. Just a Better Taxi? A Survey-Based Comparison of Taxis, Transit, and Ridesourcing Services in San Francisco. Transport Policy, 45: 168-178.

Rizki, M., Joewono, T.B., Belgiawan, T.B., dan Irawan, M.Z. 2019. Learning the Behavior of Ride-Sourcing Users Based on Their Previous Modes and Its Implication to Perceived Usefulness of Ride-Sourcing. Working Paper.

Silalahi, S.L.B., Handayani, P.W., dan Munajat, Q. 2017. Service Quality Analysis for Online Transportation Services: Case Study of GO-JEK. Procedia Computer Science, 124: 487-495. 
Young, M. dan Farber, S. 2019. The Who, Why, and When of Uber and Other Ride-Hailing Trips: An Examination of a Large Sample Household Travel Survey. Transportation Research Part A: Policy and Practice, 119: 383-392. 